\title{
Directly-Observed Treatment Strategy implementation practices in a hospital in eThekwini health district
}

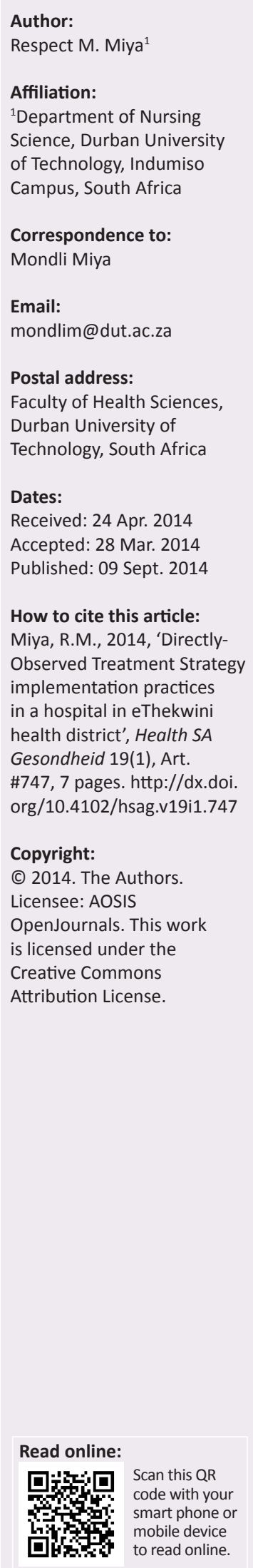

Background: The incidence rate of tuberculosis (TB) in South Africa remains high, with the country ranked as having the 14th-highest incidence rate internationally; 646 per 100000 people are infected with TB nationally, whilst KwaZulu-Natal has a provincial incidence of 1466 per 100 000. The Directly-Observed Treatment Strategy (DOTS) programme is intended to ensure both treatment completion and cure of TB, as well as its evaluation. Despite improved DOTS coverage - the focus of most DOTS studies - the incidence of drug-resistant TB suggests that issues of non-compliance are centrally responsible for ongoing concerns about the implementation and practices related to DOTS.

Objectives: The aim of the study was to explore and describe DOTS implementation practices. The objectives of the study were to explore and describe the DOTS implementation practices of professional nurses and to describe modifiable barriers to DOTS.

Method: A qualitative, descriptive, explorative study was conducted through individual interviews until saturation was reached.

Results: The study revealed that DOTS implementation was not in accordance with World Health Organization prescripts. Participants reported barriers such as limited human and material resources, ineffective communication of policy and procedural guidelines, ineffective communication between service delivery institutions and lack of continuity of care, as well as a lack of recording and reporting.

Conclusion: The study recommended a comprehensive recruitment process to facilitate greater training and employment of more permanent health professionals to combat TB in the community; and to re-launch the DOTS programme in underperforming facilities. This would give much needed momentum to efforts targeted at preventing treatment defaults amongst patients.

Agtergrond: Die voorkomskoers van tuberkulose (TB) in Suid-Afrika bly steeds hoog, waar die land internasionaal beskou word as met die 14de hoogste voorkomskoers; 646 per 100000 mense is nasionaal met TB besmet, terwyl KwaZulu-Natal 'n provinsiale voorkoms van 1466 per 100 000toon. Die punte program (DOTS) is bedoel om beide die voltooiing van behandeling en genesing van TB en die evaluering daarvan te verseker. Ten spyte van verbeterde DOTSdekking, wat die fokus van die meeste DOTS studies is, dui die voorkoms van dwelmweerstandige TB daarop dat die kwessie van nie-nakoming sentraal verantwoordelik is vir voortgesette kommer oor die implementering en praktyke wat verband hou met DOTS.

Doelwitte: Die doel van die studie was om die implementering van DOTS-praktyke te ondersoek en te beskryf. Die doelwitte van die studie was om die DOTS- implementeringspraktyke van professionele verpleegkundiges te ondersoek en te beskryf asook om veranderbare hindernisse ten opsigte van DOTS te beskryf.

Metode: 'n Kwalitatiewe, beskrywende, ondersoekende studie is uitgevoer deur middel van individuele onderhoude tot die versadigspunt bereik was.

Resultate: Die studie het getoon dat DOTS-implementering nie in ooreenstemming is met die WHO voorskrifte nie. Deelnemers berig struikelblokke soos beperkte menslike en materiële hulpbronne, oneffektiewe kommunikasie van beleid- en prosedureriglyne, oneffektiewe kommunikasie tussen dienslewerings-instellings en die gebrek aan kontinuïteit van sorg, sowel as ,n gebrek aan optekening en verslaggewing.

Gevolgtrekking: Die studie beveel ' $n$ omvattende werwingsproses aan wat groter opleiding en indiensneming van meer permanente gesondheidswerkers om TB te bekamp in die gemeenskap sal fasiliteer, asook om die DOTS-program in gemeenskappe met onderpresterende geriewe herbekend te stel. Dit sal broodnodige momentum gee aan pogings wat gerig is op die voorkoming van onderbreekte behandeling onder pasiënte. 


\section{Introduction}

The incidence of pulmonary tuberculosis (PTB) is increasing worldwide because of improperly-managed treatment programmes and poor compliance, resulting in inadequate cure rates that are exacerbated by persistant poverty, accelerated urbanisation and the explosive effect of the HIV epidemic (Okuonghae \& Korobeinikov 2007; Sonnenberg et al. 2005; World Health Organization [WHO] 2011). Suthar et al. (2012) reported that PTB is the highly infectious and most common form of the disease, tuberculosis (TB). Extra-pulmonary TB represents the spread of TB to other body systems and can affect any part of the body, most commonly pleura, lymph nodes, spine, joints, genitourinary tract, nervous system or abdomen (Suthar et al. 2012).

Almost 40 years after the introduction of chemotherapy for TB there is still a reported world incidence rate of 8 million per year (WHO 2011). In 1996, three years after the WHO declared TB to be a global emergency, the Department of Health (DoH) reported an annual mortality rate of three million people from Mycobacterium tuberculosis (MTB) and estimated that South Africa had an annual incidence rate of 147000 and a 10000 mortality rate because of TB infection. From its original acknowledgement as an important infection, the prevalence of TB has grown both progressively and exponentially, with it being estimated that up to a third of the world's population is infected with MTB - 1.7 billion of whom are living in developing countries such as South Africa (WHO 2011).

According to the WHO $(2008,2011)$, each hospital ought to adopt and implement a Directly-Observed Treatment Strategy (DOTS) programme in order to prevent the spread of TB. The programme aims to cure infected individuals, thus preventing TB drug-related complications such as multi-drug resistant (MDR) TB and extensively-drug resistant (XDR) TB. The DOTS programme was launched in South Africa in 1994 as a strategy for the effective management of the administration of TB treatment and was declared to be the biggest breakthrough thus far in the management of TB (Cullinan 2005). However, the mortality rate for TB remained high and South Africa was reported as having one of the highest mortality rates worldwide, alongside such countries as China, India and Russia (WHO 2002). In addition, the WHO report conservatively estimated that 500000 new cases of MDR-TB arise every year, with the average person with the disease infecting up to 15 other people during their lifetime (WHO 2011). Despite these results and continued education on DOTS implementation guidelines in order to combat TB, the WHO (AbouZahr \& Boerma 2010) argues that $\mathrm{TB}$ remains a global burden and reports that most developing countries are far from reaching the standards set within the Millennium Developmental Goals (WHO 2009; 2010).

\section{Problem statement}

The incidence rate of TB in South Africa is high, with the country ranked as having the 14th-highest incidence rate internationally; 646 per 100000 people are infected with TB on a national scale, whilst KwaZulu-Natal has a provincial incidence rate of 1466 per 100000 (AbouZahr \& Boerma 2010). The DOTS programme is intended to ensure both treatment completion and cure of TB; and its evaluation is recommended by the WHO $(2008,2011)$. Despite improved DOTS coverage, which is the focus of most DOTS studies, the incidence of XDR- and MDR-TB suggests that issues of noncompliance are centrally responsible for ongoing concerns about the implementation and practices related to DOTS programmes (Singh, Upshur \& Padayatchi 2007).

\section{Research purpose}

The study purpose is to explore and describe the DOTS implementation practices of nurses at a selected hospital and across affiliated clinics within the eThekwini District in the KwaZulu-Natal catchment area.

\section{Research objectives}

The objectives of the study were twofold:

- Explore and describe the DOTS implementation practices of professional nurses.

- Describe modifiable barriers to DOTS implementation practices.

\section{Research method and design}

An explorative, descriptive, qualitative design was used. According to Creswell (2009), qualitative research focuses on an in-depth exploration of a phenomenon and is presented in a narrative form which aims to offer meaningful insights. In-depth individual interviews were used to capture the depth and breadth of the range of implementation practices amongst nurses within the DOTS programme in the study setting.

\section{Study setting}

The study was undertaken in a selected hospital and its affiliated clinics within the eThekwini health district catchment area. The KwaZulu-Natal climate is alternately affected by warm temperatures and heavy rainfalls which may impair the DOTS strategy of ensuring that medication is taken continuously without interruption (AbouZahr \& Boerma 2010; WHO 2011). Unstable climatic changes have been cited as a possible cause of irregular treatment compliance, for example, when the weather is too hot a patient may feel less motivated to attend the clinic to collect the daily dose or the DOTS supporter may be tempted not to walk around door-to-door ensuring that each single dose is administered (Williams 2013).

The selected hospital is a regional hospital with 1200 beds and 17 affiliated clinics serving a large catchment area with a population of approximately 2.5 million. The catchment area is almost $15 \mathrm{~km}$ away from Durban city and the hospital is within the South Durban Municipality; peripheral clinics include Umlazi, Isipingo, Umgababa, Umbumbulu, 
Amanzimtoti, Folweni and Makhutha, as well as part of the Eastern Cape. The hospital is one of the sites for Motherto-Child Transmission (MTCT) services and has the largest crisis centre - now called the 'Place of Comfort'. The clinics included in the study are at Umlazi and the researcher intended to visit most of the clinics until data saturation had been achieved. The clinics are far apart, up to an estimated $15 \mathrm{~km}$ away from the mother hospital, with the nearest being $5 \mathrm{~km}$ away from the selected hospital.

\section{Population and target population}

The population was initially defined as all health providers actively involved in the implementation of the DOTS programme. This included Registered Nurses (RNs), Enrolled Nurses (ENs), DOTS supporters and Community Health Workers (CHWs). However, when the study was conducted, CHWs or DOTS supporters were not available at the study sites and their participation as a collective could not be elicited. The target population of this study thus comprised the nurses who were responsible for the implementation of DOTS. The sample was determined by the number of nurses involved directly in the implementation of DOTS and who were both available and willing to participate. The selected hospital had limited suitable participants, so nurses working with PTB and DOTS programmes in peripheral clinics were recruited and included until data saturation had occurred. The researcher purposively sampled nursing staff who were involved actively in DOTS programmes in the selected hospital and clinics until data saturation was achieved after 15 participants had been interviewed. The researcher started at the selected regional hospital and found nurses who were involved actively in the care of TB clients, then interviewed individual research participants. This initial process provided nine interviewees. The remaining 6 participants who were interviewed were identified purposively and came from the nearest clinic, which was $5 \mathrm{~km}$ from the four nearest clinics to the regional hospital. Two of the clinics contributed one participant each and the other 2 clinics each contributed two participants to the full sample of 15 participants who were interviewed. Of the 15 participants identified, two participants from clinic two described themselves as PTB coordinators and DOTS supporters. In the case of these two participants, the terms PTB coordinators, DOTS supporters and nurse were used interchangeably. Table 1 offers a diagrammatic overview of the participant sample that took part in the study.

\section{Data analysis}

Data were analysed using the content analysis process outlined by Elo and Kyngäs (2008). An inductive development of categories was applied. The main aim was to build a descriptive analysis of the participants' DOTS implementation practices in order to evaluate associated structure and process standards and to build a replicable and valid method for making specific inferences from the text (data collected) to other states (data interpreted) or properties of its source (Mayring 2000).

\section{Ethical considerations}

To address the ethical issues, the research proposal was submitted for approval to the University of KwaZulu-Natal (UKZN)'s Ethics Committee and the Provincial Department of Health in KZN. In addition, the researcher completed the UKZN's online research ethics course. Potential participants were provided with an information and consent sheet which made specific reference to the following:

- Participation in the study being voluntary and withdrawal before the completion of the interview being possible without repercussion for potential participants.

- Participation or non-participation in the study having no influence on the participants' employment.

- There being no direct benefits from participation in the study.

- Anonymity and the coding of data (participants' responses) ensuring no direct link between individual participants and their responses.

- Only the researcher and research supervisor having access to the raw data and reassurances of their commitment to confidentiality.

In ensuring confidentiality and combating social desirability bias, the informed consent form did not request each participant's full name, but rather numbers were assigned to identify the participants. Only the researcher had the information that linked participants' numbers to their identities. This information was password protected and would only be accessed if required during a formal study audit.

\section{Trustworthiness}

Qualitative approaches are criticised because of their lack of rigour and creditability. Both reliability and validity are questioned since homogeneity of data and coefficients of determination cannot be computed (Lincoln \& Guba 1985). These authors have developed four precise criteria for qualitative research that run parallel to quantitative terminology:

- Credibility (internal validity): how truthful are particular findings? The researcher ensured truthfulness of the reported experiences of the nurses in the DOTS

TABLE 1: Sampling procedures for the study.

\begin{tabular}{ll}
\hline Population source & Purposively-recruited participants \\
\hline Regional hospital & 9 participants \\
Clinic 1 (less than $5 \mathrm{~km}$ from the regional hospital) & 2 participants \\
Clinic 2 (between $5 \mathrm{~km}-8 \mathrm{~km}$ from the regional hospital) & $\begin{array}{l}2 \text { participants (these participants referred to themselves interchangeably as PTB coordinators, nurses } \\
\text { and DOTS supporters) }\end{array}$ \\
Clinic 3 and Clinic 4 (more than $8 \mathrm{~km}$ from the regional hospital) & Each contributed 1 participant to a total of 2 participants \\
Total sample of participating nurses & $n=15$ participants \\
\hline
\end{tabular}

PTB, pulmonary tuberculosis; DOTS, Directly Observed Treatment Strategy. 
programme by spending a long time with the participants. Each interview lasted up to 60 minutes. The interviews were conducted in the nurses' natural work setting so as to ensure comfort and relaxation on the part of the participants.

- Dependability (reliability): are the results consistent and reproducible? Instruments that are assessed for consistency in qualitative research are the researcher and the informants, both of whom vary within the research project. To adhere to the criterion of dependability, the researcher gave an explicit description of how research results were obtained. The description provides information as to how reproducible the study might be or how unique the situation is.

- Confirmability (objectivity): how neutral are the findings in terms of whether they are reflective of the informants and the inquiry and not a product of the researcher's bias and prejudice? To adhere to the criterion of objectivity, the researcher gave the completed study report to two participants to read through and confirm the truthfulness of the study.

- Transferability refers to showing that the findings have applicability in other contexts. It is attained through purposive non-probability sampling, saturation of data and thick description of the research strategy and method of the study.

\section{Results and discussion}

Thematic analysis and content analysis were used to analyse the data and to explore and describe the DOTS implementation practices of the nurses (Creswell 2009; Elo \& Kyngäs 2008). Initially, views expressed by the nurses were collated into general thematic groupings to generate 'master-theme groupings' and then, within each of these, more specific subthemes were identified. Finally, as a way of clarifying how often each theme was expressed, the appearance of 'descriptive terms' was counted and expressed through quantitative content analysis. Content analysis has been used widely in nursing studies as a systematic and objective method in the quantification of qualitative data (Creswell 2009; Mayring 2000). The researcher maintained accuracy in data analysis and interpretation by following all the steps of content analysis and categorising emergent findings using the spheres described within the Donabedian Framework (Donabedian 1980). Findings therefore focused on the DOTS structure, process and outcomes in keeping with the three categories described within the Framework.

\section{Preparation phase}

First, three copies were made of the handwritten transcripts in order to facilitate notations within the transcription and the entire text was read. The research data were reviewed on several occasions in order to gain an understanding of the text; the first reading was just a general overview of the text whilst the second review focused on the identification of thematic words within the text (using Donabedian's tripartite framework; Donabedian 1980), such as structure, policies and procedures of the DOTS programme, staff and material establishment, client identification and process: functional design and implementation, needs determination, participation and cooperation and assessment of achievement. Different colour pens were utilised in order to highlight the main themes and categories. These were then transcribed to a coding sheet. The integrated method in data analysis, namely that of Donabedian's tripartite framework and content analysis, facilitated the exploration and description of the implementation processes used in the DOTS programme. The model identifies three important influences on care quality and, to this end, the reporting on the DOTS programme specifically speaks to issues related to 'structure', 'process' and 'outcome'. Within the results about structure, participants reported on the characteristics of the physical and organisational setting in which they delivered care. With regard to process, skills used to provide healthcare - including preventive, diagnostic, therapeutic and rehabilitative aspects of care - were reported on. Outcomes, as perceived by nurses were specifically delineated and here, feedback from participants focused on the impact that DOTS programme implementation had on patient, treatment and service outcomes.

\section{Open coding and establishment of categories}

The second review focused on underlining the thematic words, structure and process standards detailed in the conceptual framework (Donabedian's tripartite framework; Donabedian 1980) used to categorise the content into themes and subthemes. Within the text, areas such as perception of roles, structure, policies and procedures in the DOTS programme, staff and material establishment were given attention. Different colour pens were utilised to highlight themes and subthemes which were then transcribed to a coding sheet. The integrated method in data analysis, that of Donabedian's tripartite framework and content analysis, made it much easier to explore and describe the implementation processes used in the DOTS programme. Participants' perceptions of DOTS and the manner in which the programme was implemented in the clinical setting were reflected under the three thematic categories, namely structure, process and outcome, in line with the spheres identified by Donabedian (1980).

\section{Structure issues highlighted within the data Education and training}

From the sample that participated in the study, only one participant had received specific training in DOTS, other participants had not done so and indicated that their learning had taken the form of unofficial peer teaching, mentoring and modular courses in the basic nurse training. In addition, two $(13 \%)$ of the participants suggested that the DOTS programme was not part of their basic training curriculum. All participants agreed that the DOTS programme was in existence, but the hospital participants $(n=7 ; 50 \%)$ reported no contact with the designated community health workers responsible for DOTS, nor were they involved in, or aware of, any training rendered to any person regarding DOTS: 
'No special interest or training was considered; I was allocated for PTB management on basis of being a health professional and have developed love PTB patients [sic] ...' (Professional nurse, female, 42 years)

'I have no special objectives for training whoever wishes to be a volunteer; the training authority is not granted, only the District office allocates people to work as volunteers.' (Professional nurse, female, 45 years)

\section{Attitudes}

One of the core objectives of a DOTS programme is improving the quality of life facilitated by daily support to PTB clients whilst on treatment (WHO 2009). Participants' comments regarding the impact of DOTS on quality of life and healthcare outcomes reflected pessimistic attitudes, specifically regarding patient motivation and the staff's ability to cope with the workload. Participants expressed a fearful and pessimistic attitude toward PTB:

'... [T] he DOTS programme is not fully functional and it [is] beyond our means to revitalise it.' (Professional nurse, female, 34 years)

'... TB is dangerous and is not well controlled.' (Enrolled nurse, female, 39 years)

\section{Human resources and accessibility}

All 15 participants $(100 \%)$ made specific reference to the overwhelming workload, with some linking this to the fact that there are insufficient staff members to respond to a large and often transient population spread over such a large area:

'... [O] ur catchment area is vast and we have a high patient movement, patients move from one address to the other and we [are] mainly responsible for injections.' (Enrolled nurse, female, 54 years)

'Our patients are not from around, they [are] from all over South Africa, just here in Durban for employment, when they decide to go, no one informs us and they are not permanent in their addresses [sic].' (Professional nurse, female, 56 years)

Participants made direct reference to the need for community workers who will act as DOTS supporters:

'The government must employ people who shall work with us to observe treatment administration on daily basis; were are short staffed to be going door-to-door and patients are less motivated to come to our facility on $[a]$ daily basis for treatment, so we rely on their verbal information about treatment taking [sic].' (Professional nurse, female, 52 years)

Hospital-based participants reported a complete lack of knowledge of and/or contact with community healthcare workers and/or DOTS supporters:

'I have never seen a DOTS supporter and would not regard myself as one....' (Professional nurse, female, 45 years)

Whilst clinic-based participants reported staff shortages because of a lack of financial remuneration, it was evident from their responses that they had some level of support from non-professional community healthcare workers. Clinic-based participants used the terms 'community health workers' and 'DOTS supporters' interchangeably to identify non-nurse workers who supported nursing staff in providing care to hospital and clinic patients. As reflected in the extracts below, clinic-based participants had access to DOTS supporters working as community health workers and reported that patients were allocated to specific DOTS supporters:

'Our DOTS supporters do not get financial assistance from the Health department and this tempers with motivation levels of supporters. It is difficult to demand patients from our DOTS supporters that we know so well that they do not get paid [sic], they are just volunteers.' (Professional nurse, female, 54 years)

\section{Policy and procedural guidelines}

Participants made specific reference to inadequate implementation of policy, their assumption being that there are no policies or procedural guidelines. All participants denied having seen DOTS guidelines, policies or any documents in their facilities regarding how the DOTS programme is managed. Many participants' comments related specifically to a lack of procedural guidelines for responding to defaulters:

'We have no DOTS guidelines and yet we are expected to work beyond duty [sic] ...' (Professional nurse, male, 37 years).

'... [N]o documents [were] required from us at any stage and we did not know that we should be keeping DOTS documents in this facility. We are not involved in training volunteers and we were not told on how to manage them when they default service delivery [sic].' (Professional nurse, female, 50 years)

\section{Participants' perceptions and descriptions of their practice \\ General role performance}

Although some of the participants referred to themselves as PTB coordinators and DOTS supporters, these were not their official job titles. As the data collection process unfolded, there was no visible practice demarcation between operational managers, professional nurses and enrolled nurses, or between DOTS supporters and PTB coordinators.

Of the participants who referred to themselves as PTB coordinators $(n=13 ; 86 \%)$, two were in managerial positions and perceived themselves as being solely responsible for sputum collection, issuing of results, administering injections, issuing food supplements and other clinical duties ranging from the observation of vital signs to liaising with transport in order to ensure that PTB drugs are delivered timeously and that specimens are sent to laboratories. Those participants that referred to themselves as DOTS supporters $(n=2 ; 13 \%)$ stated that their role was to ensure that daily medication was administered as prescribed, that there was proper communication between themselves and the patients on TB treatment and, finally, that they were also responsible for home-based care and tracing of defaulters. The differences between PTB coordinators and DOTS supporters were not reflected in the practices of the participants and the researcher opted for presenting the findings as a group collective, given the raised concerns of shortage and inconsistency in 
the current DOTS programme implemented in a selected hospital and its affiliated clinics.

Participants reported a patient classification system as follows: new cases (on six months' treatment) and re-treatment cases (on injections, MDR-TB on injections and referrals on the basis of their conditions).

All 15 participants' (100\%) practices reflected concerns with daily injections, specifically those related to re-treatment and MDR-TB cases, education regarding how to take the treatment, dispensing of PTB medication, collection of sputum specimens and dietary health education (including issuing food supplements parcels) and referral of critically-ill patients from the clinics to the hospital. Comments also reflected the participants' assumptions that families were involved in compliance:

'I give injections on daily basis ... ; patients take own treatment at home and have their relatives to assist.' (Enrolled nurse, female, 42 years).

'I am solely responsible for injections of re-treatment and MDR clients.' (Enrolled nurse, female, 34 years)

The critical role in the cure of PTB and prevention of MDRand XDR-TB, namely, of witnessing that each tablet is taken, was not mentioned by any of the participants and none said that they account for each dose taken. Several participants focused their energies on the MDR-TB clients, thus neglecting the clients on straight forward PTB treatment.

'Our main concerns are patients on injections as no relatives are always available to assist with injections. Our workload is high and we only focus on injections on daily basis and sputum collection.' (Enrolled nurse, female, 42 years)

\section{Practice response to defaulters}

Despite the core practice of DOTS being the direct observation of medication ingestion, participants reported not doing this and having little, if any, effective strategy for responding to defaulters:

'The District office is solely responsible for tracing defaulters and no formal outcome is given to us as health workers in PTB management; the programmes are somehow centralised by the District Office and we have no significant contribution as employees.' (Professional nurse, female, 48 years)

When the question of improving the DOTS programme was addressed, participants expressed strong opinions and emotions relating to the time and energy required to implement DOTS correctly within such resource-poor settings. In addition to limitations related to resources, issues related to training of clinicians were specified as being a source of inconsistency in the care provided. A number of process challenges were highlighted; in particular, emphasis was given to the lack of clear protocol guiding practitioners with regard to best practices. In addition, the lack of clear patient-tracing protocol was noted as being a key barrier to best practice. The participants' comments suggested feelings of impotence with regard to responding to these challenges, as well as dissatisfaction with government, specifically inadequate policies related to training, allocation of support personnel and tracing of clients.

\section{Limitations of the study}

The study was done at one selected hospital and its affiliated clinics; thus it is unlikely that the sample was representative of the entire catchment area and findings can therefore not be generalised to other areas in KwaZulu-Natal or South Africa. Secondly, although reassurances of confidentiality and anonymity were addressed in the information and consent sheet, it is possible that the respondents' answers might reflect a social desirability bias, although given the content of the transcripts this is considered to be a small possibility. The study was qualitative and the results cannot be generalised; there is thus a need to conduct similar studies in other areas of KZN.

\section{Recommendations}

In keeping with the application of the Donabedian framework (Donabedian 1980), recommendations focused on issues related to structure, process and outcomes. With regard to structure, it is important to prioritise issues related to the improvement of staff competence through ensuring that all nursing staff receives DOTS training. The training should focus particularly on skills development in the evaluation and monitoring processes. Education about and training in the recommended DOTS implementation processes is imperative for positive outcomes. It is suggested that personnel working with PTB clients must have intensive training and their knowledge must be evaluated and certificated regularly.

Process recommendations should focus on issues that were identified as being sources of inefficiency in the implementation of DOTS programmes. The most significant area that was reported as a consistent flaw within the system related to a lack of clarity in the process to trace patients so that they were not lost to follow up. The recommendation in this respect identifies a need to develop clear and systematic processes for patient tracing - processes that identify clearly where the responsibility for tracing should be located. Further change in policy is suggested which specifies that patients be traced locally rather than at the district level. It is suggested that the provision of resources be available to make this possible (human and/or structural eg. telephone budgets); this could be effective and efficient and would facilitate compliance-reducing PTB-related complications.

It is specifically suggested that the district office disseminate information regarding DOTS policy and practice guidelines that include tracing procedures, programme evaluation tools, patient contracts, designated DOTS supporter contracts and information systems for recording and data collection, specifically for defaulters and traced patients.

Regarding the lack of human resources, it is recommended that statistics (PTB incidence and prevalence) be used to 
determine an effective, efficient staff: patient ratio and that these ratios be supported by central government policy with the result that more personnel become trained and employed in permanent positions. Further to the lack of human resources, DOTS supporters should be sourced and employed in permanent positions so as to provide them with financial security and boost their morale and motivation.

Audit tools should be disseminated in order to implement continuous evaluation of the DOTS programme and to ensure quality and effectiveness and support budgetary requests. This process should be supported by inspections of DOTS centres on the part of the district authorities and interaction with employees in order to facilitate motivation.

It is suggested that further research should adopt an action research approach in an attempt to solve problems through a plan-act-reflect-plan cycle.

\section{Conclusion}

The participants' comments reflected the main themes of perceived non-responsibility for DOTS in its entirety, an overwhelming workload and a need to focus on specific aspects of PTB treatment as a way of giving structure to the treatment processes. The findings reflected a poorlyimplemented DOTS programme in the selected hospital and its affiliated clinics. Suggested challenges include adequate record keeping, improved human and structural resources, clear policy guidelines that are supported by resource provision to allow for effective and efficient defaultertracing strategies and formal training on PTB management programmes and processes.

\section{Acknowledgements}

The researcher wishes to thank all the participants for their time and assistance, as well as the related stakeholders who ensured the success of the current study.

\section{Competing interests}

The author declares that he has no financial or personal relationship(s) which may have inappropriately influenced him in writing this article.

\section{References}

AbouZahr, C. \& Boerma, T., 2010, 'Five years to go and counting: Progress towards the Millennium Development Goals', Bulletin of the World Health Organization 88(5), 324.

Creswell, W.P., 2009, Research design: Qualitative, quantitative, and mixed method approaches, 3rd edn., Sage Publications, Lincoln.

Cullinan, K., 2005, Hospital battles to fight drug-resistant TB, viewed 25 May 2010 from http://www.hst.org.za/news/20040730 [updated link viewed 13 April 2014, from http://www.hst.org.za/news/hospital-battles-fight-drug-resistant-tb]

Donabedian, A., 1980, Explorations in quality assessment and monitoring. Vol. I. The definition of quality and approaches to its assessment, Health Administration Press, Ann Arbor, MI.

Elo, S. \& Kyngäs, H., 2008, 'The qualitative content analysis process', Journal of Advanced Nursing 62(1), 107-115.

Lincoln, Y.S. \& Guba, E.G., 1985, Naturalistic inquiry, Sage Publications, Ltd., London.

Mayring, P., 2000, 'Qualitative content analysis', Forum: Qualitative Social Research 1(2), 120-130, viewed 17 June 2014, from http://www.qualitative-research.net/ index.php/fqs/article/view/1089

Okuonghae, D. \& Korobeinikov, A., 2007, 'Dynamics of tuberculosis: the effect of direct observation therapy (DOTS) in Nigeria,' Mathematical Modelling of Natural Phenomena 2(1), 101-113.

Singh, J.A., Upshur, R. \& Padayatchi, N., 2007, 'XDR-TB in South Africa: no time for denial or complacency', PLoS Med 4(1), e50.

Sonnenberg, P., Glynn, J.R., Fielding, K., Murray, J., Godfrey-Faussett, P. \& Shearer, S., 2005, 'How soon after infection with HIV does the risk of tuberculosis start to increase? A retrospective cohort study in South African gold miners', Journal of Infectious Diseases 191(2), 150-158.

Suthar, A.B., Lawn, S.D., Del Amo, J., Getahun, H., Dye, C., Sculier, D. et al., 2012, 'Antiretroviral therapy for prevention of tuberculosis in adults with HIV: A systematic review and meta-analysis', PLoS Med 9(7), e1001270.

Williams, B., 2013, The impact of ART for HIV on TB, South African Centre for Epidemiological Modeling and Analysis, viewed 15 December 2013, from http:// www.who.int/hiv/topics/artforprevention/williams.pdf

World Health Organization, 2002, An expanded DOTS framework for effective tuberculosis control: Stop TB communicable diseases, WHO, Geneva.

World Health Organization, 2008, Implementing the WHO stop TB strategy: A handbook for national tuberculosis control programmes, WHO, Geneva.

World Health Organization, 2009, Guidelines for surveillance of drug resistance in tuberculosis, 4th edn., WHO, Geneva.

World Health Organization, 2011, TB prevalence surveys: A handbook, viewed 17 June 2014, from http://apps.who.int/iris/bitstream/10665/44481/1/9789241548168 eng.pdf 